\title{
The impact of local public policies on sports performance. Oradea - An example of success
}

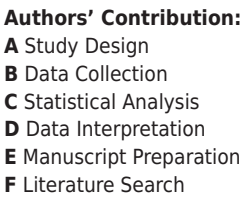

\author{
Sorin Buhaş ${ }^{1 \mathrm{ABF}}$, Raluca Buhaş ${ }^{2 \mathrm{CDE}}$, Vasile Grama ${ }^{1 \mathrm{ABF}}$, Grigore Vasile Herman ${ }^{1 \mathrm{CDE}}$, \\ Paul Dragoș ${ }^{1 \mathrm{ABF}}$ \\ ${ }^{1}$ Faculty of Geography, Tourism and Sport, University of Oradea, Oradea, Romania \\ 2 Faculty of Social Sciences, University of Oradea, Oradea, Romania
}

\section{abstract}

European, national and local public policies have a crucial role when it comes to social and economic development. Based on European and national frameworks, local public administration develops and implements local public policies based on the community needs in order to reach a high level of local development. Among other sectors, sport plays a major role in the local development. Our paper aims to outline the role of local public authorities from Oradea, Romania, in supporting high-performance sport at a local level through local public policies. In Oradea a high-performance sport is represented by the Municipal Sports Club; therefore, our analysis focuses on the impact of local public policies on the sports activity of the club. The study methodology is mixed, based on document analysis and individual interviews. Research results show a clear link between the decision of local public authorities to get involved in local sports activity and the achievement of outstanding results by local sports teams. Consistent financial support, high quality sports infrastructure, transparent public-private partnerships, as well as strong partnerships between various local public authorities are the keys to developing performance sport.

Key words: local public authorities; European, national and local public policies; sports performance.

\section{article details}

Article statistics: Word count: 5,222; Tables: 1; Figures: 3; References: 58

Received: June 2021; Accepted: October 2021; Published: November 2021

Full-text PDF: http://www.balticsportscience.com

Copyright @ Gdansk University of Physical Education and Sport, Poland

Indexation: Celdes, Clarivate Analytics Emerging Sources Citation Index (ESCI), CNKI Scholar (China National Knowledge Infrastructure), CNPIEC, DOAJ, EBSCO - Central \& Eastern European Academic Source, EBSCO - SPORTDiscus, EBSCO Discovery Service, Google Scholar, Index Copernicus, J-Gate, Naviga (Softweco, Primo Central (ExLibris), ProQuest - Family Health, ProQuest - Health \& Medical Complete, ProQuest - Illustrata: Health Sciences, ProQuest Nursing \& Allied Health Source, Summon (Serials Solutions/ProQuest, TDOne (TDNet), Ulrich's Periodicals Directory/ ulrichsweb, WorldCat (OCLC)

Funding: This research received no specific grant from any funding agency in the public, commercial, or not-for-profit sectors.

Conflict of interests: Corresponding author:

Open Access License:
Authors have declared that no competing interest exists.

Paul Dragoș - Department of Physical Education, Sport and Kinetotherapy, The Faculty of Geography, Tourism and Sport, Oradea, Romania, email: paul.f.dragos@gmail.com; phone number: +40 770193130 Derivatives 4.0 International (https://creativecommons.org/licenses/by-nc-nd/4.0/), which permits use, distribution, and reproduction in any medium, provided the original work is properly cited, the use is non-commercial and is otherwise in compliance with the license. 


\section{INTRODUCTION}

For the last several months, the world has been dominated by the coronavirus pandemic that effeAccepted as written documents which have been endorsed, including statements and decisions defining goals, priorities and main directions for attaining these goals, public policies provide a direct link between the vision and day-to-day operations of an organization $[1,2]$. Policies identify key activities and provide a general strategy for decision-makers on how to manage issues as they arise [3, 4]. This is done by offering all actors limits and a range of alternatives that can be used to guide the decision-making process. Policies not only offer guidance, consistency, responsibility, efficiency, clarity and control but also guide the actions of all persons involved or connected with the organization in regard to any area of activity in which the organization has jurisdiction [5]. Policy provides an organizing structure and guidance for collective and individual behavior [6]. It may be defined as legislative or regulatory action taken by federal, state, city, or local governments, government agencies, or nongovernmental organizations such as schools or corporations. A policy includes formal and informal rules and design standards that may be explicit or implicit [7]. There are many challenges related to the rapid evolution of sport and the legislation and regulations used by public sports authorities in Europe. Therefore, it is fundamentally important for organizations to develop clear and easy to implement policies [8].

Lately, there has been a noticeable development of national policy documents on physical activity promotion [9-11]. Good policy-making is tough. But its correct implementation leads to a better view regarding the inner problems, identifies possible solutions, and ultimately selects the best options for community development. It is important for local public authorities (LPA) to realize that they need to adopt correct and coherent local public policies in order to generate development and performance. We can state that there is a direct relationship between physical education, school physical activity, school sports and academic performance [12-14].

Sport is a positive factor in society, contributing to smart, sustainable and inclusive growth and new jobs through its positive effects on social inclusion, education and training and public health. Houlihan [15] states that sport has been transformed from an essentially private, politically marginal social activity to an important focus for governments.

Sport helps to increase social security and reduce health spending by improving the health and productivity of the population and ensuring a higher quality of life [16-18]. According to Bloyce and Smith [19], the sport policy-making process is very complex due to the increasing government intervention in the sport policy. For this reason, the development fields are continually changing in response to the increasing political, social and cultural significance of sport.

Achieving sporting success is of increasing importance to the public and to governments, so the countries increased the level of public funding [20]. Regional actors (municipalities and regions) play a crucial role in financing sport and access to sport and should be increasingly involved in related discussions at EU level [21]. But there is no model for comparing and increasing the efficiency and effectiveness of elite sport investment and management systems [22]. However, a successful public policy in sport can be evaluated through financial support, talent identification, training facilities and international competition [23].

\section{FROM EUROPEAN TO NATIONAL AND LOCAL LEVEL THE ROLE OF PUBLIC POLICES IN SPORT DEVELOPMENT}

\section{PUBLIC POLICIES IN SPORT AT THE EU LEVEL, ACHIEVEMENTS, DOCUMENTS, FUNDING}

At the European level, with the entry into force of the Lisbon Treaty in December 2009, the EU also acquired responsibilities in the field of sport, being responsible for developing 
an evidence-based policy and encouraging cooperation and management of initiatives in support of physical activity and sport throughout the world [24]. In the period 2014-2020, a specific budget line was established for the first time under the Erasmus+ program to support projects and networks in the field of sport. 1.8\% of the annual budget of Erasmus+ is dedicated to activities related to sport [25].

Among the achievements in the field of European public policies, we can mention the White Paper on Sport (2007), which set out a number of objectives, including improving the role of sport in society, promoting public health through physical activity, stimulating volunteering and improving the economic dimension of sport [26].

The 2007 White Paper on Sport paved the way for the Commission communication of January 2011 on the impact of the Treaty of Lisbon on sport, entitled Developing the European Dimension in Sport. This communication was the first policy document adopted by the Commission in the field of sport emphasizing the potential of sport to improve employment capacity and promote social inclusion. The document promotes the exchange of good practices on transparent and sustainable sports funding and the monitoring of state aid law in the field of sport.

The most important document of the European sports policy is represented by the EU Work Plan for Sport adopted by the Education, Youth, Culture and Sport Council, with the three component parts from 2011, 2014 and 2017 and which concerns the integrity of sport, its economic dimension and the relationship between sport and society, focusing mainly on good governance, innovation in sport and social inclusion. In 2016, the Council discussions on improving the integrity, transparency and good governance of major sporting events, even more emphasize the importance of sporting events to celebrate the performance, values and benefits of sport in a national and international context. Member States are invited to incorporate integrity and transparency in future work on sport at the EU level, to support the implementation of criteria and procedures related to good governance, and to identify and develop models for publicprivate cooperation and exchange good practices regarding this cooperation. The hosting of major sports events creates economic benefits for post-industrial countries where the sportsrelated service sector is a key to development and employment [27].

\section{PUBLIC POLICIES IN SPORT AT THE NATIONAL LEVEL, LAWS, REGULATIONS AND NATIONAL PROGRAMS}

Public policies are coordinated programs of action undertaken by central and local authorities in order to address issues on the governmental and public agenda [28, 29]. Public policies aim to solve problems and involve decisions on how financial, human, material, informational, time and resources are allocated for the provision of quality public services, in terms of efficiency, effectiveness and economy by central and local public administration authorities [30, 31].

Public policy in the field of physical education and sports aims to stimulate high-level sports, with priority to the branches and events included in the Olympic Games program, taking into account tradition and significant and constant contribution to the representation and increase of Romania's prestige [32]. It also aims for the development of the material base of the sports activity in order to ensure the conditions for the practice of physical education, sports for all, performance sports, as well as for the organization of national and international competitions [33].

The strategy for strengthening the capacity of the public administration (SCAP 20142020) was approved by Government Decision no. 909/2014 for the consolidation of the public administration 2014-2020 and the establishment of the National Committee for 
the coordination of the implementation of the Strategy for the consolidation of the public administration 2014-2020 [34]. One of the directions of action from the General Objective II: implementing a successful management in public administration, Specific Objective II.1 of SCAP 2014-2020 aims to increase the coherence, efficiency, predictability and transparency of the decision-making process at the level of local public administration, in order to respond coherently to the needs of local communities, by introducing the approach of public policies in the decision-making process at the level of local public authorities. Another direction of action within SCAP 2014-2020 refers to an improvement in the correlation of the budgetary component with the strategic component within the decision-making process at the local level and the development of a multiannual budgetary planning system [35].

In Romania, the public policy focusing on sport is represented by the regulations stipulated in Law no. 350/2005 on the regime of non-reimbursable financing from public funds allocated to non-profit activities of general interest, of the Law on physical education and sports no. 69/2000, with the subsequent amendments and completions [36, 37]. According to these documents, there are some programs that can benefit from funding: the program 'Promotion of performance sports' P1, the program 'Sport for all' P2, and the program 'Maintenance, operation and development of the sports equipment base' P3. In 2018, the list of national sports programs will be completed with the 'Rediscover the stickball' program (P4) and the 'Romania on the move' program (P5).

The financing of sports projects initiated by the sports structures under private law and the associations on the county and Bucharest sports branch, within the public utility sports programs provided in art. 1 is carried out through non-reimbursable financing, in accordance with the provisions of Law no. 350/2005, the amount of the co-financing percentage is established within the limit of $10 \%$ for the non-reimbursable financing and the obligation to co-finance the sports programs through simple financing is eliminated.

\section{DECENTRALIZATION OF PUBLIC POLICIES - FROM CENTRAL TO LOCAL LEVEL}

With an adapted structure, the public policy documents from the central public administration can also be used locally.

The right of initiative for draft decisions is granted to local councilors, mayors, deputy mayors or citizens [38]. "The right and effective capacity of local public authorities to solve and manage, within the law, in their own name and in the interest of the local population, an important part of public affairs' reflects the principle of local autonomy and decentralization of public services, which are on the basis of the organization and functioning of the local public administration from the administrative-territorial units (Romanian Constitution, art. 120, para. (1) [39]. The aim of the exclusive decision-making competence of the LPA authorities at the level of communes, cities and municipalities is established in the Framework Law on decentralization no. 195/2006, with subsequent amendments and completions [40].

\section{LOCAL PUBLIC AUTHORITIES AS A KEY ELEMENT IN CREATING LOCAL DEVELOPMENT}

Democratic governance has to respond to the real needs of the community, efficiency, accountability and transparency must be basic principles that guide the decision-making process in the exercise of its powers by LPA. This is the main argument that supports the need to develop public policy documents.

A local policy consists of a set of concrete measures taken by local public administration authorities, both deliberative and executive. The implementation of local public policies is based on local normative acts (local council decisions, provisions of local executive bodies: 
mayors and district presidents) and must contribute to improving the living environment of the citizens of an administrative-territorial unit.

The administrative policy in Oradea has focused over the last years on performance sports. Sports funding was directed towards the Oradea Municipal Sports Club (Oradea MSC) to increase the level of performance and visibility. Oradea MSC was established in 2003 as a legal entity of public law based on the Local Council Decision no. 314 of 24 April 2003 in order to support performance sports. As a public policy, since the establishment of Oradea MSC the City Hall did not finance any other sports activity except for the performance one [41].

In order to develop sports activity and achieve high performance, a robust budget is essential. Studies highlight budget consistency as one of the major determinants in achieving high performance in sports $[42,43]$. The budget of Oradea MSC consists of direct allowance from the local budget according to annual Local Council Decisions which stipulate the amount of the budgetary allocation, and club's own revenues such as sponsorship, sports image rights, ticket sale, transfers of players, etc.

Another local public policy to support performance sports is the investment in sports infrastructure. In high performance sports, high-quality infrastructure is one of the determining conditions in obtaining sports performance [3, 44]. In Oradea, the LPA decided and financed the construction of an Olympic swimming pool by the Local Council Decision no. 175 of 26 February 2004 [45]. Initially, it was built as an open swimming pool, and in the following year, by the Local Council Decision no. 621 of 31 August 2005, a retractable roof wass built in order to offer the proper conditions to host in July 2005 the European Junior Water Polo Championship [46]. This was the first modern Olympic-sized swimming pool built in Romania after 1989. Also, on the occasion of the U18 European Women's Basketball Championship, the Multipurpose Sports Hall was completely restored in 2015 according to the Local Council Decision no. 204 of 26 March 2015. Its technological facilities enable the development of the highest-level sports competitions [47].

Due to high-level sports results, and also due to a growing interest in sports among the local community, Oradea City Hall decided to massively invest in sports infrastructure. Based on the Local Council Decision no. 92 of 18 February 2020, the complete restoration of the Olympic swimming pool was decided - an investment of 2,434,940 Euros [48]. Also, based on the Local Council Decision no. 498 of 25 June 2020, the location and the necessary documentation for the construction of a new swimming pool were handed over to the National Investment Company [49]. Based on the Local Council Decision no. 199 of 31 March 2016, Oradea City Hall handed over to the National Investment Company the location and the necessary documentation in order to build a new modern multipurpose sports hall with a capacity of 5,000 seats [50]. This multipurpose hall is now in the final phase of building. Another major investment in sports infrastructure is a modern Sports Complex, which includes a football stadium with a capacity of 16,291 seats, a hotel with SPA, conference rooms and parking places, as well as an athletics stadium. This investment was approved by the Local Council Decision no. 774 of 12 October 2020 and has an estimated value of 76,667,814 Euros [51].

As a result of local public policies, Oradea City Hall has created 4 industrial parks, offering a series of facilities to companies willing to reside here. In 2008, by Local Council Decision no. 985 of 30 October 2008, the first industrial park - Euro Business Park Oradea I (EBP I) established, reaching a number of 50 resident companies in 2019 [52]. Due to this success, Euro Business Park Oradea II (EBP II) was established three years later based on Local Council Decision no. 285 of 14 April 2011, with 33 residents in 2019 [53]. In 2012, by the Local Council Decision no. 78 of 9 February 2012 Euro Business Park Oradea III (EBP III) 
is established, having 14 residents in 2019 [54], and in 2018 by Local Council Decision no. 1165 of 12 December 2018 Euro Business Park Oradea IV (EBP IV) was created and is still under development [55].

\section{LOCAL PUBLIC POLICIES TRANSLATED INTO PERFORMANCE}

\section{RESEARCH METHODOLOGY}

The aim of our study was to investigate how LPA through local public policies influence sports performance in Oradea - Romania. At local level, high performance sport is equivalent with the results obtained by the sports teams of the Oradea MSC. For our investigation, data for Oradea MSC were analyzed in five years (2015-2020). Therefore, our research methodology comprised the following directions of investigation:

1. Document analysis on data between 2015-2020: analysis of the budget of Oradea MSC; analysis of official national competition rankings on different branches of sport - this analysis focused on top-ranked local sports teams; analysis of the dynamics of private companies residing in the business environment in Oradea;

2. Individual semi-structured interview with the Mayor of Oradea City: we aimed to present and discuss the decision of LPA to support and promote high performance sport, as well as how and on what directions. The interview guide was semi-structured and comprised 7 questions and tackled issues such as: the decision to support high-performance sport at the local level, aspects regarding Oradea MSC, public policies for the development of sports infrastructure, public policies for the development of the local business environment, future local public policies directed towards sports activity. The structure of the interview and of questions was adapted during the discussion according to the main issues approached.

The obtained data and information as well as research results are presented and discussed in an integrative manner in order to create a comprehensive image of how local public policies impact sports performance.

\section{MAIN FINDINGS}

Over last five years (between 2015 and 2020), the budget of Oradea MSC constantly increased. According to Figure 1, in 2015 the total budget of Oradea MSC was 9,563,042 Lei (approximately 1,952,641 Euro) and it grew to 16,684,521 Lei (approximately 3,405,004 Euro) in 2020. This is due to increases in both sources of the budget - allowances given by LPA, as well as own revenues mostly coming from sponsorship.

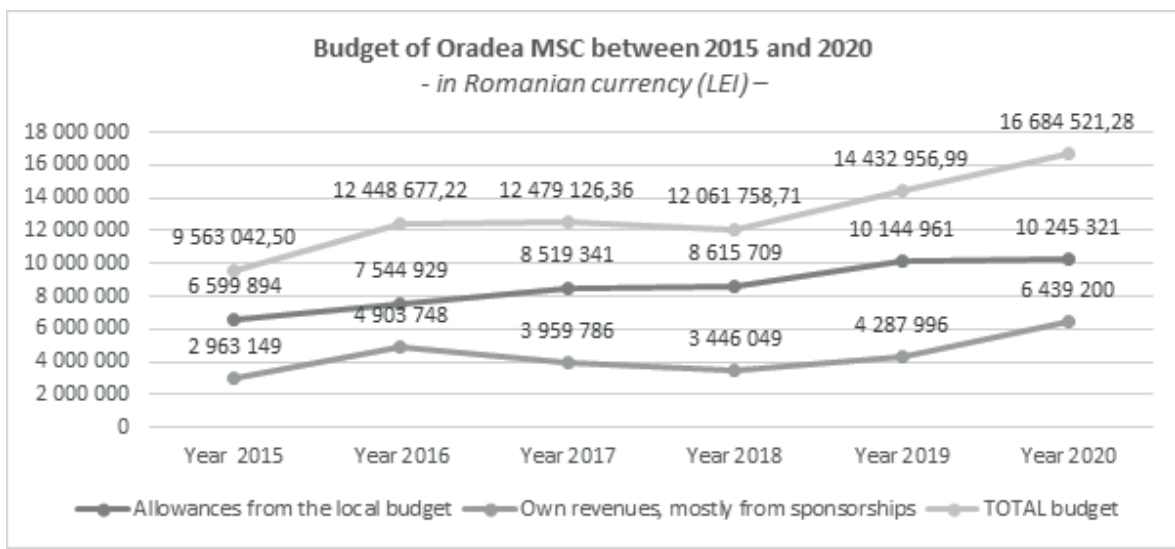


When it comes to LPA`s contribution to the club`s budget, we need to outline that the total budget of Oradea MSC has developed over the years and this is especially due to a constant increase in the value of allowances from the local budget from year to year (Figure 1).

Obviously, LPA, namely Oradea City Hall, provides the highest share in the club`s budget - more than $60 \%$ annually over the last five years (Figure 2). At this point, one aspect deserves attention: even though in 2020 the LPA share in the club`s budget registered one of the lowest values over the analyzed period (61\%), this does not mean that the values of allowances from public money decreased; on the contrary, the financial contribution of LPA in the club`s budget rose over the years (Figure 1). Thereby, this situation is to be related to the overall growth of the club`s budget every year, in 2020 achieving its highest point so far. Therefore, we can state that, due to its consistent financial contribution over the years, there is a constant preoccupation of the LPA regarding sports activity, in general, and high-performance sport, in particular.

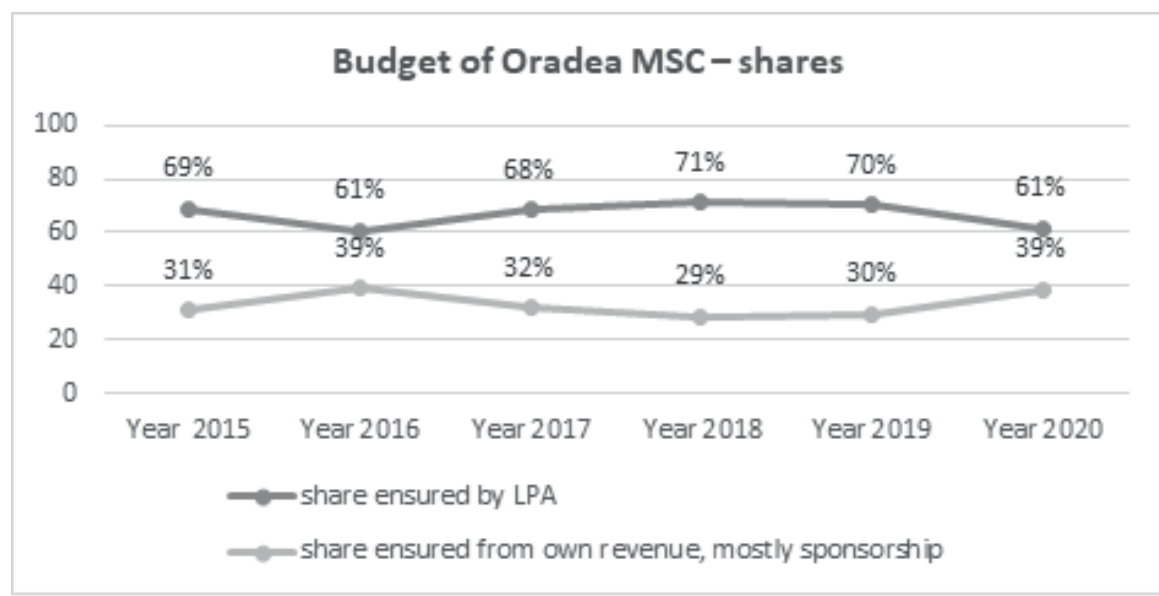

Fig. 2. Budget of Oradea MSC - shares from local public budget and sponsorship

On the other hand, approximately one third of the club's budget is ensured from own revenues (Figure 2). Nevertheless, the total budget of Oradea MSC increased as well due to higher values of own revenues in the last years. It is to mention that sponsorship coming from the private business environment in Oradea is the most important component of the club's own revenues, and the value of the sponsorship registers a growing trend (Figure 1). Moreover, taken into consideration that over the last five years the number of club's sponsors has increased - 13 sponsors in 2015 compared to 20 sponsors this year, we assume that this tendency will not change soon, and the value of sponsorship will continue to rise.

But how can this growing trend regarding sponsors and their financial contribution to the club `s budget be explained? At this point, other local public policies are worth mentioning as a key element to local development. Over the last years, LPA has focused intensively on the private business environment and has developed four Euro Business Parks in Oradea so far, as mentioned before.

Figure 3 shows the evolution of the number of companies residing in all four business parks in Oradea since their foundation. Every year more and more companies resided here with a total of 95 this year. The only exception for the moment, due to its recent establishment, is EBP IV with no resident companies yet. 
Number of companies in EBP I, EBP II, EBP III - Oradea

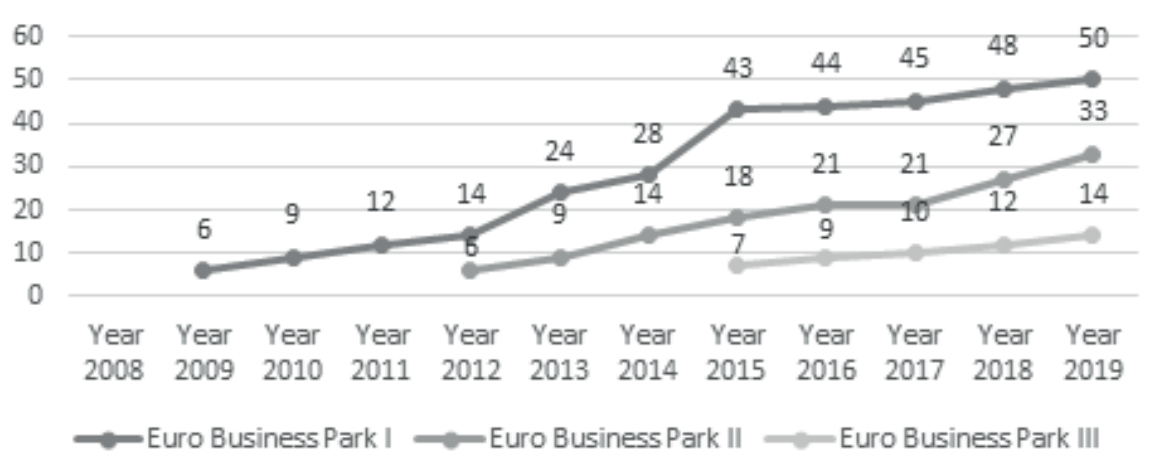

Fig. 3. Evolution of the number of companies within all Euro Business Parks in Oradea since their establishment

This constant evolution of the number of companies which decided to reside in the business parks in Oradea over the years is not random. Through specific local public policies LPA stimulated the growth of the local business environment. Important companies were attracted to EBPs in Oradea due to well-targeted facilities offered by LPA and through local public policies, such as: fiscal facilities, tax exemption on land and buildings.

We can assume that companies choose to bring their contribution to the local community also by financing local sport. Therefore, we can imply that the increase in the number of companies is reflected in the increase in their financial contribution to local sports activity. Of course, business environment directs its sponsorship mainly towards sports teams of Oradea MSC where high performance is targeted and achieved. Obviously, higher sponsorship would have a positive impact on achieving higher sports results. Therefore, if the dynamics of the number of companies in EBPs continues to increase, this could be translated into higher financial contribution to the local sport activity through sponsorship.

Even if the budget is probably the most important determinant of achieving performance in sport, it is not the only one. Likewise, we can discuss the influence of sports infrastructure. Obviously, a high quality will result in high performance obtained by sports teams. Thus, in order to support local sports teams in reaching high-performance results, LPA oriented local public policies towards the development of sports infrastructure. These elements stimulate the local development as well. Due to specific public policies, local sports teams benefit from high standard sport infrastructure for their activity: the construction and recent restoration of the Olympic swimming pool, the building of a new multipurpose sports hall and the restoration of the old one, as well as the construction of a new football stadium. This high-standard infrastructure is expected to stimulate the achievement of higher sports results by local teams. This already happened: before the construction of the Olympic swimming pool, the local water-polo team was last national champion in the competitional season 1984-1985. After the development of the Olympic swimming pool in 2004 the local water-polo team was top-ranked and has been serial national champion between 2007-2015.

The increase in the budget of Oradea MSC and proper sports infrastructure had for sure positively impacted its activity. Most sport teams from Oradea MSC reached high performance over last years, and this can be seen in the case of basket-ball, water polo and judo. Table 1 explicitly shows the official rankings of most sports teams of Oradea MSC at the national level over the last five years. It is to be noticed that the basket-ball team has managed to be top-ranked every year; moreover, over the last three years the local basket-ball team is the national champion. For 2019-2020 competitional season, the national champion in basket-ball was not declared because the championship was stopped when the emergency 
state at national level because of COVID-19 pandemic situation was declared; even so, the local basket-ball team was ranked first. Other local sports teams performed as well at the national level: the water-polo team is the vice champion of Romania, while also the local judo team is top-ranked.

Table 1. Oradea MSC - sport teams' rankings at national level

\begin{tabular}{cccc} 
Year & Basket-ball & Water polo & Judo (teams) \\
\hline 2015 & 1st place & 2nd place & 5th place \\
2016 & 3rd place & 2nd place & 1st place \\
2017 & 1st place & 2nd place & 5th place \\
2018 & 1st place & 2nd place & 5th place \\
2019 and 2020 & $\begin{array}{c}\text { Champion not declared } \\
\text { (due to the current } \\
\text { pandemic situation } \\
\text { COVID-19) }\end{array}$ & 2nd place & Did not participate due \\
& to the current pandemic & situation COVID-19
\end{tabular}

Data source: Romanian National Sports Federations $[56,57,58]$

\section{THE IMPLICATION OF LPA IN HIGH-PERFORMANCE SPORTS - AN INSIGHT}

Data obtained from an interview conducted with the Mayor of Oradea, as one of the main representatives of public authorities at the local level, adds to other research findings and helps us create a broader image on how the involvement of LPA through local public policies can support the achievement of high performance in sports activity. Results from this interview are thoroughly presented and discussed further.

The sports club Oradea MSC was established owing to a local public policy. This public policy and the involvement of the Local Council in Oradea MSC is a clear proof that LPA aimed to permanently support the development of sports performance at local level. Moreover, the support provided by LPA to sports activity led to very good results. Since its establishment, Oradea MSC had a transparent and performant management which led to the achievement of important sports results by the local sports teams, a fact that encouraged the development of more public policies in this regard as well.

'It is proven that if an investment is transparent and trustworthy, it will generate results, create performance and even attract the private environment.' - Mayor of Oradea

In terms of the club's budget, LPA finances all activities related to sports competitions (accommodation, cantonments), while salaries are ensured from external sources - sponsorship or other type of own revenues. The financial contribution coming from LPA increased over the years due to the presence of more performant local sports teams. Also, the higher the local budget is, the higher the allowances given by LPA to sport activity. The same growing trend was also outlined in the case of sponsorship coming from the private environment. Private companies were stimulated to invest in high-performance sport, thus in Oradea MSC, due to its transparency, professionalism and outstanding results. Therefore, both public and private money supports high-performance sport. On the other hand, when a local sport team has top results sponsors can benefit from it by associating their image with the team.

'This is the key to success in any sport: partnership between private environment and the local public administration. If this works, there will be results.' - Mayor of Oradea

The private business environment in Oradea grew due to local public policies aiming at local development. There is a direct connection between a well-developed private environment and the value of sponsorship for sports, so the funding opportunity increases when the local 
community has a strong private environment. Therefore, many private companies invest and support various sports activities at the local level through sponsorship, or other actions, such as the purchase of season tickets.

Over the past few years, LPA decided to massively invest and support the development of local sports infrastructure through public policies. This was motivated by the good results that the local basket-ball team was starting to have at the national level. Therefore, a bigger multipurpose hall was needed in order to have more space for more spectators, and to give the possibility for more sports teams to train.

LPA aims to continue to support local sport activity through local public policies mainly aiming to develop the sports infrastructure more. A new stadium is planned to be ready in the next three-four years, and this is considered to be a stimulus for the local football team to evolve at least in the Romanian League - Second Division. Moreover, LPA plans to build a sports complex including a new multipurpose hall, a new stadium, a sports field of the local Sports High School, as well as sports fields and a sports hall of the University of Oradea. This sports complex should definitely boost local development.

The Mayor of Oradea outlined the importance of public-private partnerships, as well as transparent partnerships between local public institutions, such as Oradea City Hall, Bihor County Council and the University of Oradea in the development of high-performance sport.

\section{DISCUSSION AND CONCLUSIONS}

Literature review and analysis of various documents and regulations point out that over the last two decades the EU has put a great emphasis on the development of sport and highperformance sport $[9,10,17,20,21,24,26]$. Physical activity provides a lot of benefits for society when it comes to social inclusion, professional and personal development, as well as public health [16-18]. Therefore, sport has become a European and a national priority for every Member State of the EU, and governments have been more involved lately in this sector through public policies. Also, high-level sports performance is becoming increasingly important, so governments have increased the level of public funding in this direction.

As a Member State of the EU, Romania has adopted the European law and policy on sports promotion and development. Thus, at the national level, public policies are directions of action on the governmental and public agenda meant to identify problems and implement solutions [36, 37]. Sports policies aim to stimulate the highest level of sports activity. They also aim to develop proper sports infrastructure to ensure optimal conditions for performance sports as well as for the organization of international competitions.

All these national public policies need to be adopted also at the local level through specific documents, programs and policies. We state that Oradea is an example of good practice in this regard, because LPA successfully transferred and implemented national public policy on sport at local level [41, 45-51]. Moreover, Oradea was one of the first Romanian municipalities to act in this direction. The LPA of Oradea has taken the initiative to develop a series of local public policies on sports through various Local Council Decisions for the interest of citizens and aiming local development. All this was possible due to the autonomy and decentralization of local public services.

Our investigation outlined the impact of local public policies on achieving sports performance. Hence, over the last five years the representative sports teams of Oradea MSC (basketball, water polo, judo) have been top-ranked in national competitions (national champions and vice champions), and successfully represented Oradea and Romania also at international 
level. Data show that among the main key elements that lead to sports performances there are the budget and an adequate sports infrastructure, components that can be conditioned and supported by local public policies.

LPA, through local public policies [41], positively impact the budget of Oradea MSC orienting its action in two lines: directly, by giving allowances to the club from the local public budget, and indirectly, by creating facilities for the private environment, thus widening the area of possible sponsors for the club. This was achieved by the establishment of four businesses parks in Oradea between 2008 and 2019 where the number of new residing companies rises every year [52-55]. So, we can assume that the establishment of the business parks due to specific local policies has indirectly helped sports performance by increasing the amount of sponsorship for the club.

Regarding sports infrastructure, Oradea was the first city in Romania after 1989 to build an Olympic swimming pool in 2004 [45]. This had a major impact on the development and performance of the local water-polo team, a fact proven by ten national titles, as well as by the organization of the European Junior Championship in 2005. This direction of action was kept also for other types of local sports infrastructure: the massive funding from LPA for the restoration of a multipurpose hall - hence, the local basketball team was three times national champion [47]. Following this good practice, LPA is building a new multipurpose hall in Oradea at the highest standards, and a Sports Complex that integrates all necessary facilities for high-performance sports [50]. LPA aims to continue to support performance sports in Oradea also in the future through local public policies, given its success so far.

Obviously, high-performance sport is a complex and multicausal phenomenon. Our investigation aimed only to demonstrate the contribution and importance of LPA's involvement, through public policies, in supporting and stimulating performance in sports. Of course, other components, such as coaches' professionalism, the players' quality, media advertising, are other key-elements in achieving sports performance, and these may constitute future directions of study.

\section{REFERENCES}

[1] Garcia B, de Wolff M, Yilmaz S. Issue framing and institutional constraints in EU agenda-setting: An analysis of European Union Sport Policy. J Contemp Eur Res. 2018;14(1):23-39.

[2] Herman GV, Banto N, Caciora T, et al. Tourism in Bihor County, Romania. Trends and Prospects. Folia Geogr. 2020;62:87-105.

[3] Hallmann K, Wicker P, Breuer C, Schönherr L. Understanding the importance of sport infrastructure for participation in different sports-findings from multi-level modeling. Eur Sport Manag Q. 2012; 12(5):525-44. https://doi.org/10. 1080/16184742.2012.687756

[4] Hartmann-Tews I. Social stratification in sport and sport policy in the European Union. Eur J Sport Soc. 2006; 3(2):109-24. https://doi.org/10.1080/16138171.2006.11687784

[5] Chappelet JL. Beyond governance: The need to improve the regulation of international sport. Sport Society. 2018 21(5):724-34. https://doi.org/10.1080/17430437.2018.1401355

[6] Parent MM. Stakeholder perceptions on the democratic governance of major sports events. Sport Manag Rev. 2016 19(4):402-16. https://doi.org/10.1016/j.smr.2015.11.003

[7] Schmid TL, Pratt M, Witmer L. A framework for physical activity policy research. J Phys Act Health. 2006; 3(s1):S20-9. https://doi.org/10.1123/jpah.3.s1.s20

[8] Chaker AN. Good governance in sport: A European survey. Council of Europe; 2004.

[9] Daugbjerg SB, Kahlmeier S, Racioppi F, et al. Promotion of physical activity in the European region: Content analysis of 27 national policy documents. J Phys Act Health. 2009; 6(6):805-17. https://doi.org/10.1123/jpah.6.6.805

[10] Shephard RJ, Lankenau B, Pratt M, et al. Physical activity policy development: a synopsis of the WHO/CDC consultation, September 29 through October 2, 2002, Atlanta, Georgia. Public Health Rep. 2004;119(3):346-51. https://doi. org/10.1016/j.phr.2004.04.013

[11] Cristea D, Cristea A, Dragos P. Considerations regarding pedagogical practice of physical education students at gymnasium. GeoSport Society. 2017;6(47)

[12] Trudeau F, Shephard RJ. Physical education, school physical activity, school sports and academic performance. Int J Behav Nutr Phys Act. 2008;5(1):1-2. https://doi.org/10.1186/1479-5868-5-10

[13] Cristea D.I., Motoc I., Pop A.C. Aspects regarding the integration of children with special educational needs through participation in physical education. Balt J Health Phys Act. 2020;12SpecIss1:79-86. https://doi.org/10.29359/ BJHPA.12.Spec.Iss1.09 
[14] Zadarko E, Zbigniew B, Szabo-Alexi P, et al. Physical Education and Students' Healts Promotion Platform as an Element of European Union's Health Strategy Against the Level of Cardiorespiratory Fitness of Students From Poland, Slovakia, Romania. Studia Universitatis Babes-Bolyai, Educatio Artis Gymnasticae. 2011;56(3):107-116.

[15] Houlihan B. Sport, policy and politics: A comparative analysis. Routledge; 2002. https://doi.org/10.4324/9780203160640

[16] Pratt M, Macera CA, Wang G. Higher direct medical costs associated with physical inactivity. Physician Sportsmed. 2000;28(10):63-70. https://doi.org/10.3810/psm.2000.10.1237

[17] Cavill N, Foster C, Oja P, Martin BW. An evidence-based approach to physical activity promotion and policy development in Europe: Contrasting case studies. Promot Educ. 2006;3(2):104-11. https://doi.org/10.1177/10253823060130020104

[18] Ilieș DC, Buhaș R, Ilieș A, Gaceu O, Oneț A, Buhaș S, Rahotă D, Dragoș P, Baiaș S, Marcu F, Oneț C. Indoor Air Quality Issues. Case Study: The Multipurpose Sport Hall of the University of Oradea.2018; Environmental Engineering \& Management Journ al (EEMJ) 17 (12), 2999 - 3005.

[19] Bloyce D, Smith A. Sport policy and development: An introduction. Routledge; 2009. https://doi. org/10.4324/9780203890684

[20] Green M, Houlihan B. Comparative elite sport development: Systems, structures and public policy. Great Britain: Elsevier; 2008. https://doi.org/10.4324/9780080554426

[21] Communication from the Commission to the European Parliament, the Council, the European Economic and Social Committee and the Committee of the Regions - Developing the European Dimension in Sport, Brussels, 18.1.2011 $\operatorname{COM}(2011) 12$ final.

[22] De Bosscher V. Sport Policy factors Leading to International Sporting Success. Brussel: VUB Press; 2007.

[23] Olszewski-Strzyżowski DJ. European societies' access to sport-the European Union actions. GeoSport Society. 2018;9(2):71-81.

[24] Daniel BU. Uniunea Europeană-Principiile generale de organizare. Revista Transilvană de Ştiinţe Administrative. 2002; 4(7):148-65.

[25] European Commission. Erasmus+ Education, Training, Youth \& Sport, 2014-2020. 2013.

[26] European Commission. White Paper on Sport. 2007.

[27] Taylor P, Gratton C. The economics of sport and recreation: an economic analysis. Routledge; 2002. https://doi. org/10.4324/9780203474839

[28] Buda D. The Role of Public Authorities in Regional Development and the Implementation of the Cohesion Policy. Transylv Rev Adm Sci. 2017;2(41):3-13.

[29] Matei L. Representing the Local Interests in Governmental Policy Making-The Romanian Experiment. The Status of Inter-Governmental Relations and Multi-Level Governance in Europe and the US, Milan. 2008; 43-62.

[30] Rusu O, Cuza A. Sport and Politics-Unilateral or Joint Interests? Romanian Case. Int J Sport Culture Sci. 2016; 4(Special Issue 2):507-14. https://doi.org/10.14486/IntJSCS575

[31] Hințea CE, Profiroiu MC, Țiclău TC. Strategic planning and public management reform: The case of Romania. Transylv Rev Adm Sci. 2015;11(SI):30-44.

[32] Houlihan B, Zheng J. The Olympics and elite sport policy: Where will it all end?. Int J History Sport. 2013;30(4):338-55. https://doi.org/10.1080/09523367.2013.765726

[33] Niesyto J, Lovasova R. The EU Funds as a Change of The Regional Development in Reference to The Sport Infrastructure in Years 2007-2013. Polish Journal of Management Studies. 2015; 11(1):100-112.

[34] Government Decision no. 909/2014 published in the Official Gazette no. 834 bis dated 17.11.2014 on the approval of the Strategy for Strengthening Public Administration 2014-2020 and the establishment of the National Committee for coordinating the implementation of the Strategy for Strengthening Public Administration 2014-2020.

[35] Romanian Ministry of Public Works, Development and Administration, 'The Strategy for Strengthening the Capacity of the Public Administration 2014-2020 (SCAP 2014-2020). [Online] at http://www.dpfbl.mdrap.ro/documents/ strategia administratiei publice/Strategia pentru consolidarea administratiei publice 2014-2020.pdf, accessed October $\overline{2} 2,2020$.

[36] Law no. 350/2005 on the regime of non-reimbursable financing from public funds allocated for non-profit activities of general interest, published in the Official Gazette, Part I no. 1128 of December 14, 2005.

[37] Law on physical education and sports no. 69/2000, published in the Official Gazette, Part I no. 200 of May 9, 2000.

[38] Șandor DS, Tripon CR. Citizen's Perception about Public Administration Reforms in Romania. Transylv Rev Adm Sci. 2008;4(24):111-22.

[39] Romanian Constitution, published in the Official Gazette of Romania, Part I, no. 233 of November 21 , 1991.

[40] Framework law on decentralization no. 195/2006, published in the Official Gazette, Part I no. 453 of May 25, 2006.

[41] Decision of the Local Council of Oradea Municipality no. 314 of April 24, 2003, regarding the approval of the establishment of the 'Oradea Municipal Sports Club'.

[42] Miragaia D, Ferreira J, Carvalho A, Ratten V. Interactions between financial efficiency and sports performance. J Entrepreneurship Public Policy. 2019; 8(1):84-102. https://doi.org/10.1108/JEPP-D-18-00060

[43] Srithongrung A. An evaluation of performance-based budget reform in Asian countries. Int J Public Adm. 2018;41(4):257-67.

[44] Wilson W. Sports infrastructure, legacy and the paradox of the 1984 Olympic Games. Int J History Sport. 2015 2(1):144-56

[45] Decision of the Local Council of Oradea Municipality no. 175 of February 26, 2004, regarding the construction of an Olympic swimming pool in Oradea.

[46] Decision of the Local Council of Oradea no. 621 of August 31, 2005, regarding the Covering of the Oradea Olympic Pool.

[47] Decision of the Local Council of Oradea Municipality no. 204 of March 26, 2015, on ensuring the necessary logistics for the development in good conditions of the European Women's Basketball Championship 2015.

[48] Decision of the Local Council of Oradea Municipality no. 92 of February 18, 2020, on Capital Restoration and Modernization of the Olympic Swimming Pool. 
[49] Decision of the Local Council of Oradea Municipality no. 498 of June 25, 2020 on the handing over to the National Investment Company of the site in order to execute the investment objective Swimming Pool.

[50] Decision of the Local Council of Oradea Municipality no. 199 of March 31, 2016 on handing over to the National Investment Company the location of the investment objective Multipurpose Hall with a capacity of 5000 seats.

[51] Decision of the Local Council of Oradea Municipality no. 774 of October 12, 2020 on the investment objective Works of local public interest for educational and sports constructions and the related infrastructure - Construction of Sports Complex.

[52] Decision of the Local Council of Oradea Municipality no. 985 of October 30, 2008 regarding the establishment of Eurobussines Parc Oradea, with the destination of industrial park.

[53] Decision of the Local Council of Oradea Municipality no. 285 of April 14, 2011 regarding the establishment of Eurobussines Parc Oradea no. 2, with the destination of industrial park.

[54] Decision of the Local Council of Oradea Municipality no. 78 of February 9, 2012 regarding the establishment of Eurobussines Parc Oradea no. 3, with the destination of industrial park.

[55] Decision of the Local Council of Oradea Municipality no. 1165 of December 12, 2018 regarding the establishment of Eurobussines Parc Oradea no. 4, with the destination of industrial park.

[56] Romanian Basketball Federation, Men's National Basketball League, 2020, [Online] at https://www.frbaschet.ro/ campionat-masculin/liga-nationala-de-baschet-masculin\#mbt:17-303\$t\&0=1, accessed October 10, 2020.

[57] Romanian Judo Federation, National results, 2020, [Online] at https://www.frjudo.ro/anii-precedenti/, accessed October 10, 2020

[58] Romanian Polo Federation, 2020, [Online] at http://frpolo.ro/wp-content/uploads/2019/04/Camp.seniori-2018-2019, accessed October 10, 2020

. 